\title{
Multi-location evaluation of gene pyramided lines of MTU 1010 and JGL 1798 against bacterial blight of rice
}

\author{
G. PADMAJA ${ }^{1,3}$, CH. V. DURGA RANI ${ }^{2}$, G. UMA DEVI ${ }^{3}$, A. YUGANDER ${ }^{1}$, C. SRINIVAS ${ }^{4}$, R.M. SUNDARAM ${ }^{1}$ \\ and G.S. LAHA ${ }^{\text {* }}$ \\ ${ }^{1}$ ICAR-Indian Institute of Rice Research, Rajendranagar, Hyderabad 500030 , Telangana, India \\ ${ }^{2}$ Institute of Biotechnology, ${ }^{3}$ Department of Plant Pathology, ${ }^{4}$ Department of Entomology, Prof. Jayashankar Telangana State \\ Agricultural University, Rajendranagar, Hyderabad 500 030, Telangana, India
}

Received: 28 June 2017/ Accepted: 26 August 2017/ Published online: 31 August 2017

(C) Indian Phytopathological Society 2017

\begin{abstract}
Cottondora Sannalu (MTU 1010) and Jagtial Sannalu (JGL 1798) are widely cultivated rice varieties in Telangana and Andhra Pradesh and very well-accepted among the farmers because of their high yield, slender grain and preferred cooking quality. Despite being popular, these varieties are susceptible to different pests and diseases including bacterial blight (BB), caused by Xanthomonas oryzae pv. oryae (Xoo). Two BB resistance genes viz., xa13 and Xa21 were introgressed in these two varieties using marker assisted backcross breeding. Homozygous lines possessing BB resistance genes xa13 or Xa21 and their combination were evaluated for BB resistance with multiple Xoo isolates under controlled condition in glass house and also at different hot spot locations in the states of Telangana and Andhra Pradesh, India. Both the recurrent parents (MTU 1010 and JGL 1798), TN1 (susceptible check variety) and Improved Samba Mahsuri (resistant check variety) were also subjected for resistance evaluation. All the gene-pyramided lines were highly resistant to BB both under glasshouse and field condition. Individually, BB resistance gene xa13 showed higher level of resistance than Xa21. The resistance level was higher in the lines possessing both the BB resistance genes in comparison to the lines possessing single BB resistance genes. The results showed that combination of BB resistance genes xa13 and Xa21 can provide broad level of resistance against BB in Telangana and Andhra Pradesh.
\end{abstract}

Keywords: Bacterial blight, resistance, rice, Xanthomonas oryzae pv. oryzae

Rice is the principal staple food crop in India and rice production has so far kept pace with the growing population, primarily due to large scale cultivation of high yielding, high-input demanding, and semi-dwarf nonlodging rice varieties (Gnanamanickam, 2009). Rice varieties like Samba Mahsuri (BPT 5204), Cottondora Sannalu (MTU 1010), Jagtial Sannalu (JGL1798), Swarna (MTU 7029) and Tellahamsa are widely cultivated by the farmers in Telangana and Andhra Pradesh. These varieties are widely cultivated by the farmers because of their high yield potential, medium-slender grain type and desired cooking quality. In spite of their popularity, they are susceptible to many pests and diseases including bacterial blight (BB) of rice caused by Xanthomonas oryzae pv. oryzae (Xoo).

BB has become a major production problem in rice cultivation in India and elsewhere (Devadath, 1992; Sridhar, 2002; Win et al., 2013). In general, BB is a monsoon (wet) season problem of high yielding rice varieties cultivated with high nitrogen application, especially in irrigated and rainfed lowland ecosystems. The extent of yield loss due to BB can be as high as $50 \%$ or more depending on the crop stage during infection, environmental conditions, rice cultivars and

\footnotetext{
${ }^{*}$ Corresponding author: lahags @yahoo.co.in
}

amount of nitrogenous fertilizers applied (Laha et al., 2009). Epidemic form of the disease was reported from north-western India during 1979 and 1980 (Mew, 1987), Palakkad district of Kerala during 1998 (Priyadarishini and Gnanamanickam, 1999) and several rice growing areas of Andhra Pradesh during 2010 and 2013 (Yugander et al., 2014). The disease appeared in very severe form in coastal Andhra Pradesh during 2014 following the severe cyclone 'HUDHUD'. The disease has become a serious constraint in several rice growing areas of Warangal, Nizamabad and other districts of Telangana (Laha et al., 2016). As the chemical control of the disease is not very effective, cultivation of disease resistant varieties is the most successful and eco-friendly alternative for the management of BB (Mew, 1987; Sundaram et al., 2014). Till date, at least 40 BB resistance genes have been identified from various sources (Sundaram et al., 2014; Kim et al., 2015) and few of these genes been used in resistance breeding program. However, Xoo is highly diverse in nature (Hunjan et al., 2014; Mondal et al., 2014; Yugander et al., 2017) and resistant varieties particularly those carrying single BB resistance genes have become susceptible due to appearance of new virulence of the pathogen (Mew et al., 1992; Laha et al., 2007). The durability of resistance can be increased by pyramiding multiple BB resistance 
genes through marker assisted selection (MAS). Some of the major $\mathrm{BB}$ resistance genes which have been widely used in gene-pyramiding programs in India are xa13 and Xa21 (Sundaram et al., 2014). Several studies in India have reported that combination of $X a 21$ and $x a 13$ provides high level and broad spectrum resistance to Indian Xoo population (Joseph et al., 2004; Mishra et al., 2013; Mondal et al., 2014; Ellur et al., 2016a). Keeping in view the broad spectrum effectiveness of Xa21 and xa13 combination, these two BB resistance genes were selected for pyramiding in these two popular rice cultivars. In this study, we report the performance of MAS-derived lines of MTU 1010 and JGL 1798 possessing BB resistance genes xa13 and Xa21, either individually or in combination.

\section{MATERIALS AND METHODS}

\section{Plant materials and Xoo isolates}

The experimental materials consisted of 5 homozygous NILs (near isogenic lines) in the background of popular rice variety MTU 1010 (C1-20-3 possessing $B B$ resistance gene xa13, C1-13-3 possessing $X a 21$ and C1-20-2, C1-20-4 and C1-20-5, all possessing both xa13 and $X$ a21) and 3 homozygous NILs in the genetic background of JGL 1798 (C5-42-47, C5-45-48 and C549-44, all possessing both xa13 and $\mathrm{Xa21}$ ). The recurrent parents MTU 1010 and JGL 1798, TN1 (susceptible check variety) and Improved Samba Mahsuri (resistant check variety) were also included for resistance evaluation. The NILs were developed at the Institute of Biotechnology, PJTSAU, Hyderabad using marker assisted backcross breeding.

Resistance evaluation of these NILs was carried out both in the glasshouse under controlled condition and also at different hot spot locations. Under glasshouse condition, the NILs were evaluated against 10 different Xoo isolates. The Xoo isolates included IX-006 (Warangal, Telangana), IX-015 (Aduthurai, Tamil Nadu), IX-020 (ICAR-IIRR, Telangana), IX-027 (Chinsurah, West Bengal), IX-050 (Maruteru, Andhra Pradesh), IX-148 (Cuttack, Odisha), IX-133 (Raipur, Chhattishgarh), IX266 (Nandhiyal, Andhra Pradesh), IX-281 (Tanuku, Andhra Pradesh) and IX-372 (Guntur, Andhra Pradesh). These Xoo isolates were obtained from ICAR-IIRR stock cultures maintained at the Department of Plant Pathology, ICAR-IIRR, Hyderabad. The resistance evaluation of the NILs at different hot spots was done by artificially inoculating the entries with local Xoo isolates. The Xoo strains from those locations were isolated following the standard procedures (Yugander et al., 2014) and maintained on modified Wakimoto's Agar (MWA) (Sucrose 20g; peptone 5g; Calcium nitrate 0.5g; $\mathrm{Na}_{2} \mathrm{HPO}_{4}$ $1.82 \mathrm{~g}$; Ferrous sulphate 0.05g; Agar 20g; Distilled water $1000 \mathrm{ml} ; \mathrm{pH} 6.8-7.0)$ at $4^{\circ} \mathrm{C}$ for regular use and in $15 \%$ glycerol at $-70^{\circ} \mathrm{C}$ for long term preservation. The pathogenicity of all the Xoo isolates was checked before use by inoculating them on 40 days old TN1 (susceptible variety) plants in glass house using 3-day old bacterial suspension $\left(10^{8-9} \mathrm{cfu} / \mathrm{ml}\right)$.

\section{Genotyping of the NILs}

The NILs were screened with gene-specific markers to detect the presence of target BB resistance genes viz., xa13 and Xa21. The primers used were xa13-prom for xa13 (Sundaram et al., 2011) and pTA248 for Xa21 (Ronald et al., 1992). The details of the primers used are presented in the Table 1. The NILs, recurrent parents (MTU 1010 and JGL 1798) and donor parent (Improved Samba Mahsuri) were raised in plastic pots and leaf samples (5-7 cm leaf pieces) were collected from 20 days old seedlings of each entry for DNA isolation. Extraction of plant genomic DNA was carried out following Zheng et al. (1995). The DNA was washed with chilled ethanol $(70 \%)$, dried at room temperature overnight and dissolved in $50 \mathrm{ml}$ of sterile distilled water or TE buffer (10 mM Tris- $\mathrm{HCl}, \mathrm{pH} 8.0$ and $1 \mathrm{mM}$ EDTA, pH 8.0) and preserved at $-20^{\circ} \mathrm{C}$ for future use. The quality of the DNA was checked by running in $0.8 \%$ agarose gel.

Presence of BB resistance genes in the NILs was detected through PCR using the gene-specific markers. The reaction mixture $(20 \mu \mathrm{l})$ consisted of $20 \mathrm{ng}$ of template DNA, 5 pmoles of each primer, $0.5 \mu$ dNTPs $(2.5 \mathrm{mM}), 2 \mu \mathrm{l} \mathrm{PCR}$ buffer $(10 \mathrm{X})$ and $1 \mu \mathrm{l}$ of Taq DNA polymerase $(1 \mathrm{u} / \mathrm{ml})$. PCR amplification was performed in a thermal cycler (Applied Biosystems, USA) using initial denaturation at $94^{\circ} \mathrm{C}$ for $5 \mathrm{~min}, 30$ cycles of denaturation at $94^{\circ} \mathrm{C}$ for $30 \mathrm{~s}$, annealing at $55^{\circ} \mathrm{C}$ for $30 \mathrm{~s}$ and extension at $72^{\circ} \mathrm{C}$ for $1 \mathrm{~min}$, followed by a final extension at $72^{\circ} \mathrm{C}$ for $7 \mathrm{~min}$ and then finally incubating at $4^{\circ} \mathrm{C}$. The PCR products $(20 \mu \mathrm{l})$ were mixed with gel loading buffer $(40 \%$ sucrose and $0.25 \%$ bromophenol blue) and loaded in a gel containing $2 \%$ agarose in $1 \mathrm{X}$ TBE buffer. Electrophoresis was carried out for 1 hour at a constant voltage of $100 \mathrm{~V}$ and stained using ethidium bromide $(0.5 \mu \mathrm{g} / \mathrm{ml})$ and documented (Alpha Image Analysis, USA). Confirmation of BB resistance genes, xa13 and Xa21 in the NILs was done based on the amplicon size corresponding to the donor parent, Improved Samba Mahsuri possessing three BB resistance genes Xa21, xa13 and xa5.

Table 1. Details of the primers used for detection of BB resistance genes xa13 and Xa21

\begin{tabular}{|c|c|c|c|c|c|}
\hline $\begin{array}{l}\text { BB resistance } \\
\text { genes used }\end{array}$ & Markers & $\begin{array}{l}\text { Chromosomal } \\
\text { location }\end{array}$ & Sequence of the marker & Amplicon size & Reference \\
\hline xa13 & xa13 prom & 8 & $\begin{array}{l}\text { F-5'-TCCCAGAAAGCTACTACAGC-3' } \\
\text { R-5'- GCAGACTCCAGTTTGACTTC-3' }\end{array}$ & $\begin{array}{l}\text { S allele: } 250 \mathrm{bp} \\
\text { R allele: } 530 \mathrm{bp}\end{array}$ & $\begin{array}{l}\text { Sundaram } \\
\text { et al. (2011) }\end{array}$ \\
\hline Xa21 & pTA248 & 11 & $\begin{array}{l}\text { F-5'-AGACGCGGGAAGGGTGGTTCCCGGA-3' } \\
\text { R-5'-AGACGCGGGTAATCGAAAGATGAAA-3' }\end{array}$ & $\begin{array}{l}\text { S allele: } 650 \mathrm{bp} \\
\text { R allele: } 960 \mathrm{bp}\end{array}$ & $\begin{array}{l}\text { Ronald et al. } \\
\text { (1992) }\end{array}$ \\
\hline
\end{tabular}




\section{Raising of NILs, pathogen multiplication and resistance evaluation}

For glasshouse evaluation, all the entries (NILs, recurrent parents and check varieties) were line-sown in plastic trays (dimensions- $60 \times 40 \times 7 \mathrm{~cm}$ ). A mixture of soil and farm yard manure (3:1) was prepared and the trays were filled up. The trays were fertilized with N @ $2.4 \mathrm{~g} /$ tray and $\mathrm{P}_{2} \mathrm{O}_{5} @ 1.2 \mathrm{~g} /$ tray. Part of $\mathrm{N}$ and entire amount of $\mathrm{P}$ was applied as basal while remaining $\mathrm{N}$ was applied as top dressing. Each tray was used for inoculation with individual $\mathrm{Xoo}$ isolate, 35-40 days after sowing. These isolates were cultured on MWA at $28 \pm 2^{\circ} \mathrm{C}$. Using 3 days old bacterial suspension ( $\left.10^{8-9} \mathrm{cfu} / \mathrm{ml}\right), 2-3$ leaves of every plant of each entry was inoculated by leaf clipping method (Kauffman et al., 1973). Observations on disease reactions were made 15 days post inoculation by measuring the lesion length. For each entry, 3 observations were taken. The disease reactions were categorized as resistant (lesion length up to $5 \mathrm{~cm}$ ), moderately resistant (5-10 cm lesion length), moderately susceptible (10-15 cm lesion length) and susceptible (lesion length more than $15 \mathrm{~cm}$ ) (Mondal et al., 2014).

The entries were also evaluated for their reaction to BB at four hot spot locations in Telangana and Andhra Pradesh viz., Agricultural Research Institute, Hyderabad, Telangana, Regional Agricultural Research Station, Warangal, Telangana, Regional Agricultural Research Station, Jagtial, Telangana and Agricultural Research Station, Nellore, Andhra Pradesh. Each entry was transplanted in field using 25 days old seedlings. Local susceptible varieties were also included for comparison. Plants were inoculated with Xoo isolate specific to that location, 25-30 days after transplanting following clip inoculation as described above. Data were recorded by measuring the lesion length 15 days after inoculation. For each entry 3 observations were taken and disease reaction was categorized as described earlier.

\section{Data analysis}

The data from glass house and field tests were analyzed by Randomized Complete Block Design using ANOVA technique using the statistical package Statistix version 8.1. Further, least significant difference (LSD) test was applied to test the significance of treatment difference.

\section{RESULTS}

\section{Genotyping of the NILs to re-confirm the presence of $B B$ resistance genes}

The NILs were screened with gene-specific primers xa13prom and pTA248 for detecting rice BB resistance gene $x a 13$ and Xa21, respectively. Presence of target genes, xa13 and Xa21 in the NILs was identified based on the amplicon size (For xa13: 250 bp for susceptible allele in MTU 1010 and JGL 1798 and 530 bp for resistance allele in Improved Samba Mahsuri and for Xa21: 650 bp for susceptible allele in MTU 1010 and JGL 1798 and 960 bp for resistance allele in Improved Samba Mahsuri). The line C1-20-3 in the genetic background of MTU 1010 was confirmed to possess single BB resistance gene xa13 while NIL C1-13-3 was confirmed to possess single BB resistance gene Xa21 (Fig. 1a, 1b). All the remaining lines in the background of MTU 1010 (C1-20-2, C1-20-4 and C1-20-5) and JGL 1798 (C5-4247, C5-45-48 and C5-49-44) revealed the presence of both xa13 and Xa21 (Fig. 1a, 1b).

\section{Glasshouse evaluation of the NILs against multiple Xoo isolates}

The NILs, recurrent parents, susceptible and resistant checks were evaluated under glasshouse condition with 10 diverse Xoo strains belonging to different rice growing regions and different virulence groups. The lesion length of the NILs against different Xoo strains is presented in the Table 2. All the pyramided lines possessing xa13 or Xa21 or their combination exhibited resistant reaction with significantly smaller lesion lengths when compared to their recurrent parents. However the NILs with single BB resistance genes produced relatively larger lesions compared to the lines possessing both the $\mathrm{BB}$ resistance genes (Table 2). The NIL C1-20-3 possessing single BB resistance gene xa13 produced a lesion length varying

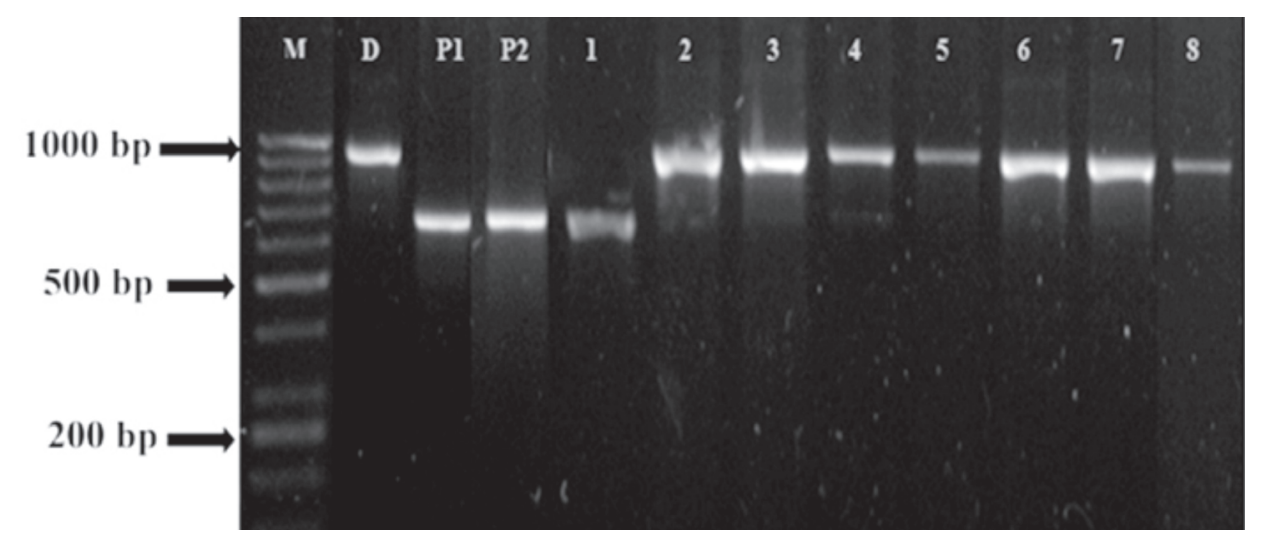

Fig. 1a. Verification of near isogenic lines for the presence of Xa21 gene with pTA248 marker; The marker pTA248 produces an amplicon size of $\sim 650$ bp for susceptible allele in MTU 1010 and JGL 1798 and $~ 960$ bp for resistance allele in Improved Samba Mahsuri; M-50 bp ladder; D-Donor (Improved Samba Mahsuri); P1-MTU 1010; P2-JGL 1798; 1-C1-20-3 (xa13); 2-C1-13-3 (Xa21); 3-C1-20-2; 4-C1-20-4 ; 5-C1-20-5; 6-C5-42-47; 7-C5-45-48; 8-C5-49-44 


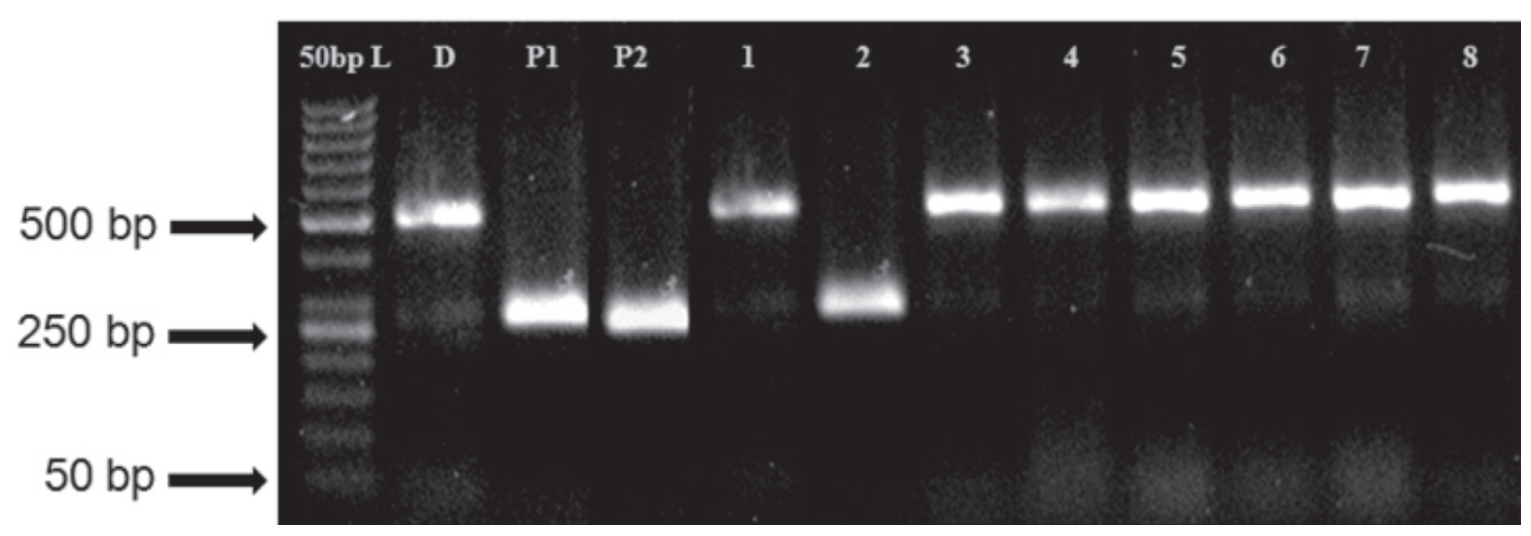

Fig. 1b. Verification of near isogenic lines for the presence of xa13 gene with xa13-prom Marker; The marker xa13-prom produces an amplicon size of $~ 250$ bp for susceptible allele in MTU 1010 and JGL 1798 and $~ 530$ bp for resistance allele in Improved Samba Mahsuri; M-50 bp ladder ; D-Donor (Improved Samba Mahsuri); P1-MTU 1010; P2-JGL 1798; 1-C1-20-3 (xa13); 2-C113-3 (Xa21); 3-C1-20-2; 4-C1-20-4 ; 5-C1-20-5; 6-C5-42-47; 7-C5-45-48; 8-C5-49-44

Table 2. Evaluation of NILs for BB resistance with different isolates of Xanthomonas oryzae pv. oryzae under glasshouse

\begin{tabular}{|c|c|c|c|c|c|c|c|c|c|c|c|}
\hline \multirow[t]{2}{*}{ NILs } & \multirow[t]{2}{*}{ Genes } & \multicolumn{10}{|c|}{ Xoo isolates/Mean lesion length $(\mathrm{cm})$} \\
\hline & & IX-006 & IX-015 & IX-020 & IX-027 & IX-050 & IX-133 & IX-148 & IX-266 & IX-281 & IX-372 \\
\hline C1-20-3 & xa13 & $3.80^{e}$ & $3.23^{e}$ & $3.83^{e}$ & $2.4^{\mathrm{e}}$ & $3.03^{e}$ & $3.3^{d}$ & $2.0^{e}$ & $5.00^{e}$ & $3.47^{\mathrm{e}}$ & $4.23^{e}$ \\
\hline C1-13-3 & Xa21 & $7.67^{d}$ & $5.77^{d}$ & $6.27^{d}$ & $3.33^{d}$ & $6.00^{d}$ & $7.73^{c}$ & $5.5^{d}$ & $6.77^{d}$ & $5.73^{d}$ & $6.00^{d}$ \\
\hline C1-20-2 & $x a 13+X a 21$ & $0.33^{g}$ & $0.20^{g}$ & $0.43^{f}$ & $0.43^{\mathrm{gh}}$ & $0.60^{g}$ & $0.6^{f}$ & $0.57^{g}$ & $0.53 \mathrm{ghi}$ & $0.33^{f}$ & $0.50^{g}$ \\
\hline C1-20-4 & $x a 13+X a 21$ & $0.43 \mathrm{fg}$ & $0.33^{g}$ & $0.27^{f}$ & $0.57^{\text {tgh }}$ & $0.57^{g}$ & $0.367^{f}$ & $0.47^{g}$ & $0.20^{i}$ & $0.33^{f}$ & $0.33^{g}$ \\
\hline$C 1-20-5$ & $x a 13+X a 21$ & $0.47^{\mathrm{fg}}$ & $0.43^{\mathrm{fg}}$ & $0.63^{f}$ & $0.93 \mathrm{fg}$ & $1.10^{\mathrm{fg}}$ & $0.5^{f}$ & $0.37^{g}$ & $0.70 \mathrm{ghi}$ & $0.30^{f}$ & $0.60^{g}$ \\
\hline C5-42-47 & $x a 13+X a 21$ & $0.80^{f}$ & $3.00^{e}$ & $1.4^{f}$ & $1.0^{f}$ & $1.83^{f}$ & 1.2 ef & $1.33^{\dagger}$ & $2.30^{f}$ & $1.00^{f}$ & $2.10^{f}$ \\
\hline C5-45-48 & $x a 13+X a 21$ & $0.37^{g}$ & $0.93^{\dagger}$ & $0.57^{\dagger}$ & $0.87^{\mathrm{fg}}$ & $1.23^{\mathrm{fg}}$ & 2.27 de & 1.67 ef & $1.13^{g}$ & $0.67^{f}$ & $0.43^{g}$ \\
\hline C5-49-44 & $x a 13+X a 21$ & $0.43^{\mathrm{fg}}$ & $0.43^{\mathrm{fg}}$ & $0.4^{f}$ & $0.47^{\text {tgh }}$ & $1.20^{\mathrm{fg}}$ & $0.43^{f}$ & $0.5^{g}$ & $1.23 \mathrm{gh}$ & $0.33^{f}$ & $0.33^{g}$ \\
\hline \multicolumn{2}{|c|}{ MTU 1010 (Recurrent parent) } & $11.0^{\circ}$ & $9.27^{c}$ & $13.00^{b}$ & $13.00^{b}$ & $7.0^{\circ}$ & $14.00^{b}$ & $11.0^{b}$ & $12.33^{b}$ & $10.00^{c}$ & $12.33^{b}$ \\
\hline \multicolumn{2}{|c|}{ JGL 1798 (Recurrent parent) } & $11.5^{b}$ & $10.00^{b}$ & $12.17^{c}$ & $11.00^{\mathrm{c}}$ & $9.0^{b}$ & $10.00^{c}$ & $15.0^{a}$ & $10.67^{c}$ & $11.00^{b}$ & $11.00^{\mathrm{c}}$ \\
\hline \multicolumn{2}{|c|}{ ISM (xa5 + xa13 + Xa21) (R Check) } & $0.4^{\mathrm{g}}$ & $0.20^{g}$ & $0.20^{g}$ & $0.20^{f}$ & $0.23^{h}$ & $0.47^{g}$ & $0.2^{f}$ & $0.37^{g}$ & $0.37^{\text {hi }}$ & $0.27^{f}$ \\
\hline \multicolumn{2}{|c|}{ TN 1 (S Check) } & $13.0^{\mathrm{a}}$ & $11.97^{a}$ & $21.00^{a}$ & $21.67^{a}$ & $25.0^{a}$ & $21.67^{a}$ & $14.17^{a}$ & $22.33^{a}$ & $21.33^{a}$ & $20.00^{a}$ \\
\hline \multicolumn{2}{|l|}{ CV (\%) } & 5.42 & 6.27 & 6.6 & 17.07 & 7.54 & 9.4 & 19.58 & 10.26 & 10.07 & 16.7 \\
\hline \multicolumn{2}{|c|}{$\operatorname{LSD}(P=0.05)$} & 0.37 & 0.41 & 0.57 & 1.44 & 0.5451 & 0.82 & 1.57 & 0.87 & 0.86 & 1.31 \\
\hline
\end{tabular}

ISM-Improved Samba Mahsuri; Figures in a column with same letters are not significantly different at $5 \%$ level of significance

from $2 \mathrm{~cm}$ (with Xoo strain IX 148) to $5 \mathrm{~cm}$ (with Xoo strain IX 266) while the NIL C1-13-3 possessing single $\mathrm{BB}$ resistance gene $\mathrm{Xa21}$ exhibited a lesion length of $3.3 \mathrm{~cm}$ (with Xoo strain IX 027) to $7.4 \mathrm{~cm}$ (with Xoo strain IX 133) (Table 2). Among these two lines, line C-20-3 with xa13 showed shorter lesion lengths compared to line C-13-3 possessing Xa21 (Table 2).

The NILs possessing both xa13 and $\mathrm{Xa21}$ in the genetic background of MTU 1010 (C1-20-2, C1-20-4 and C1-20-5) showed highly resistant reaction with significantly reduced lesion length (Table 2, Fig. 2). In these NILs, the lesion length varied from $0.2 \mathrm{~cm}(\mathrm{C} 1-20-$ 2 with IX-015 and C1-20-4 with IX-266) to $1.1 \mathrm{~cm}(\mathrm{C} 1-$ 20-5 with IX-050) (Table 2). The NILs in the background of JGL 1798 (C5-42-47, C5-45-48 and C5-49-44) possessing both the $\mathrm{BB}$ resistance genes (xa13 and $X a 21)$ also showed highly resistant reaction with significantly reduced lesion length (Fig. 2). In these NILs, the average lesion length ranged from $0.33 \mathrm{~cm}$ (C5-49-
44 with IX-281 and IX-372) to $2.30 \mathrm{~cm}$ (C5-42-47 with IX-266) (Table 2). Though 2-gene pyramided lines of both MTU 1010 and JGL 1798 showed highly resistant reaction, the average lesion lengths were slightly less in NILs of MTU 1010 compared to NILs of JGL 1798 (Table 2 ). Both the recurrent parents were moderate to highly susceptible to the Xoo isolates used in the present study with average lesion length ranging from $7-14 \mathrm{~cm}$ in MTU 1010 and $9-14 \mathrm{~cm}$ in JGL 1798. Improved Samba Mahsuri showed high level of resistance to the Xoo isolates with an average lesion length ranging from 0.2 $0.4 \mathrm{~cm}$ while the susceptible check TN1 showed highly susceptible reaction with average lesion length ranging from 13-15 cm (Table 2).

\section{Resistance evaluation of NILs at hot spot locations}

Pyramided lines, possessing xa13 and Xa21, either singly or in combination in the genetic background of MTU 1010 and JGL 1798 were also evaluated under field conditions 


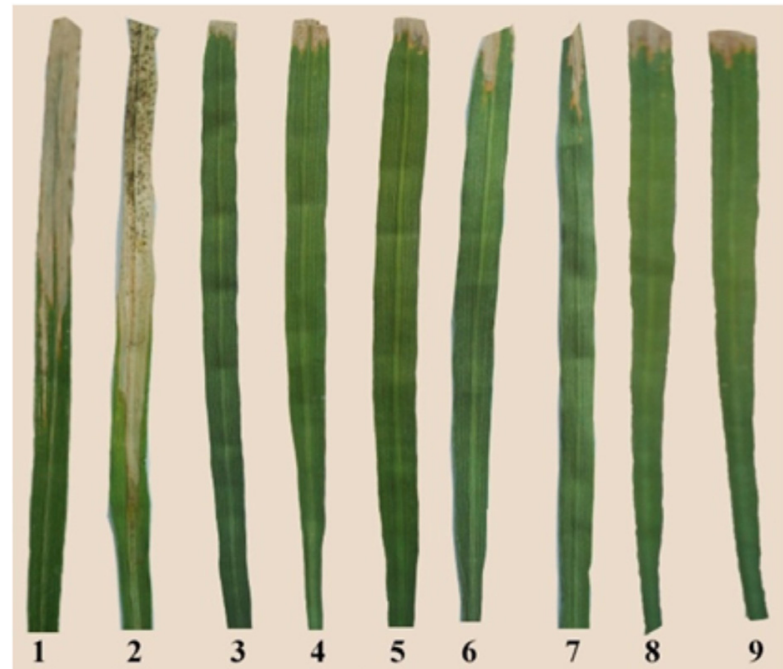

Fig. 2. BB reaction of 2-gene ( $x a 13$ and $X a 21)$ pyramided lines of MTU 1010 and JGL 1798 to Xoo isolate IX-020 under glasshouse condition; 1-MTU 1010; 2-JGL 1798; 3Improved Samba Mahsuri; 4-C1-20-2; 5- C1-20-4; 6- C120-5; 7- C5-42-47; 8- C5-45-48; 9- C5-49-44

at four different hot spot locations in Telangana and Andhra Pradesh having different weather conditions. The Plants were clip-inoculated at maximum tillering stage (Kauffman et al., 1973) with local representative Xoo isolates which were established from BB infected leaves collected from research stations or nearby farmer's fields. The observations were taken on lesion length $(\mathrm{cm}) 15$ days after inoculation. Data on lesion length were subjected to combined analysis to study the performance of the entries across different locations (Table 3). The analysis revealed a wide variation in the lesion length of different gene pyramided lines across different locations indicating virulence of the Xoo isolates used and influence of weather factors in expression of BB symptoms. Perusal of mean lesion length data revealed that all the NILs possessing xa13 and Xa21 either singly or in combination in the background of MTU 1010 or JGL 1798 produced significantly smaller lesions compared to recurrent parents and susceptible checks (Table 3). Mean data across the locations indicated that among the NILs possessing single BB resistance genes, line C1-20-3 possessing BB resistance gene xa13 performed better (mean lesion length $3.38 \mathrm{~cm}$ ) compared to NIL C1-13-3 possessing BB resistance gene Xa21 (mean lesion length $6.7 \mathrm{~cm}$ ). The mean data revealed that the NILs possessing combination of both xa13 and Xa21 showed significantly shorter lesion length (ranging from $0.91 \mathrm{~cm}$ in $\mathrm{C} 5-49-44$ to $1.73 \mathrm{~cm}$ in $\mathrm{C} 5-42-47$ ) compared to NILs possessing single genes (Table 3 ). Analysis of mean data revealed that 2-gene pyramided lines, C1-20-2 and C1-20-4 in the genetic background of MTU 1010 were on par with each other and performed slightly better than C1-20-5 (another 2-gene pyramided lines in the background of MTU 1010). Similarly, 2-gene pyramided line C5-49-44 in the background of JGL 1798 performed slightly better than other two 2-gene pyramided lines i.e. C5-42-47 and C5-45-48 (also in the background of JGL 1798). The lines C1-20-5, C5-42-47 and C5-45-48 possessing BB resistance genes $\mathrm{Xa} 21$ and xa13 showed comparatively larger lesions at Nellore which could be due to variation in the Xoo strains.

Table 3. Mean lesion length (cm) of NILs against BB at different hot spot locations in Telangana and Andhra Pradesh

\begin{tabular}{|c|c|c|c|c|c|c|}
\hline \multirow[t]{2}{*}{ NILs } & \multirow[t]{2}{*}{ Genes } & \multicolumn{4}{|c|}{ Locations/Lesion length $(\mathrm{cm})$} & \multirow[t]{2}{*}{ Mean } \\
\hline & & WGL & RNR & JGL & NLR & \\
\hline C1-20-3 & xa13 & $2.87 \mathrm{mn}$ & $3.70 \mathrm{kl}$ & $2.77^{n}$ & $4.17^{k}$ & $3.38^{e}$ \\
\hline C1-13-3 & Xa21 & $5.37^{i}$ & $7.47^{i}$ & $5.73^{j}$ & $8.23^{h}$ & $6.70^{d}$ \\
\hline C1-20-2 & $x a 13+X a 21$ & 0.67 rstuvw & 0.93 rstuv & 1.07 arstu & 1.87 op & $1.13^{g}$ \\
\hline C1-20-4 & $x a 13+X a 21$ & $0.77^{\text {rstuvw }}$ & $0.53^{\text {tuvw }}$ & $0.87^{\text {rsturw }}$ & $2.00^{\circ}$ & $1.04^{\mathrm{g}}$ \\
\hline C1-20-5 & $x a 13+X a 21$ & 0.63 rstuvw & 0.87 rsturw & 1.20 pqrst & $3.53 \mathrm{klm}$ & $1.56^{f}$ \\
\hline C5-42-47 & $x a 13+X a 21$ & $1.73^{\mathrm{opq}}$ & 1.30 opqr & $0.83^{\text {rstuvw }}$ & $3.07 \mathrm{Imn}$ & $1.73^{f}$ \\
\hline C5-45-48 & $x a 13+X a 21$ & $1.27^{\text {pqrs }}$ & 1.20 parst & 0.57 stuvw & $3.17 \mathrm{lmn}$ & $1.55^{f}$ \\
\hline C5-49-44 & $x a 13+X a 21$ & 1.10 qrstu & 0.50 tuvw & 1.03 qrstu & 1.00 rstuv & $0.91^{\mathrm{g}}$ \\
\hline MTU-1010 & Recurrent parent & $10.33^{g}$ & $12.33^{e}$ & 11.67 ef & $14.17^{c}$ & $12.13^{b}$ \\
\hline JGL-1798 & Recurrent parent & $10.67^{g}$ & $10.50^{\mathrm{g}}$ & $10.40^{g}$ & $11.43^{f}$ & $10.75^{c}$ \\
\hline ISM & Resistant check & 0.47 uvw & 0.43 uvw & $0.20 w$ & $0.30 \mathrm{ww}$ & $0.35^{h}$ \\
\hline $\mathrm{TN}-1$ & Susceptible check & $13.17^{d}$ & $15.00^{b}$ & $12.33^{e}$ & $18.33^{a}$ & $14.71^{\mathrm{a}}$ \\
\hline Mean & & $4.09^{c}$ & $4.56^{b}$ & $4.06^{c}$ & $5.94^{a}$ & \\
\hline \multicolumn{7}{|l|}{ CV (\%): 9.5} \\
\hline \multicolumn{7}{|c|}{$\operatorname{LSD}(P=0.05)$ (Treatment): 0.36} \\
\hline \multicolumn{7}{|c|}{$\operatorname{LSD}(P=0.05)$ (Location): 0.21} \\
\hline \multicolumn{7}{|c|}{ LSD $(P=0.05)$ (Treatment $x$ Location): 0.72} \\
\hline
\end{tabular}

WGL-Warangal, Telangana; RNR-Rajendranagar, Telangana; JGL-Jagtial, Telangana; NLR-Nellore, Andhra Pradesh; Figures in a column with same letters are not significantly different at $5 \%$ level of significance 


\section{DISCUSSIONS}

Bacterial blight is a major disease of rice in India which can significantly reduce the yield. Though, more than 40 $\mathrm{BB}$ resistance genes have been reported from various sources, the effectiveness of individual BB resistance genes varies from region to region, due to difference in pathogen population structure. Pyramiding multiple resistance genes for different biotic stresses provides in-built resistance to the popular and widely adopted cultivars and thereby reduces the yield loss due to biotic stresses. A number of research laboratories are carrying out gene pyramiding program by introgressing multiple $\mathrm{BB}$ resistance genes in popular rice varieties to provide in-built resistance against this disease (Sundaram et al., 2008; 2009; Salgotra et al., 2012; Hajira et al., 2014; Ellur et al., 2016a; Ellur et al., 2016b). In this study, two broadspectrum BB resistance genes, Xa21 and xa13 were pyramided in two popular rice varieties, MTU 1010 and JGL 1798 to provide in-built BB resistance.

Evaluation of NILs against multiple Xoo isolates under glasshouse conditions revealed that NILs with both xa13 and Xa21 provided broader and higher level of resistance to Xoo compared to the NILs which have single BB resistance gene. The lesion length in lines possessing both the $\mathrm{BB}$ resistance genes ranged from 0.2-2.3 cm compared to the lines possessing single BB resistance gene (lesion length ranged from 2-7.4 cm). However, among the NILs possessing single BB resistance genes, line $\mathrm{C} 1-20-3$ with $x a 13$ showed slightly better level of resistance compared to line C1-13-3 with Xa21. In a similar study, Laha et al. (2007) showed high level of resistance of 2 and 3-gene pyramided lines in the background of popular rice variety Swarna to multiple isolates of Xoo under glasshouse condition. Hari et al. (2011) demonstrated broad spectrum resistance of KMR3R (restorer line of rice hybrid $\mathrm{KRH} 2$ ) lines possessing BB resistance gene Xa21 to multiple Xoo strains under glasshouse condition. Many earlier studies have reported that $\mathrm{BB}$ resistance gene xa13 provides broad-spectrum resistance to Xoo (Lore et al., 2011; Mishra et al., 2013; Yugander et al., 2017).

A large number of studies have shown the performance of different gene pyramided lines to multiple isolates of Xoo under field conditions. Basmati rice varieties Pusa Basmati 1121 and Pusa Basmati 6 were improved for blast and $\mathrm{BB}$ resistance by incorporating two BB resistance genes ( $x a 13$ and $X a 21)$ and two blast resistance genes ( $\mathrm{Pi} 2$ and $\mathrm{Pi54}$ ) using marker assisted backcross breeding (Ellur et al., 2016a). Sundaram et al. (2008) evaluated four 3-gene pyramided (xa5 + xa13 + Xa21) lines of Samba Mahsuri under AICRIP (All India Coordinated Rice Improvement Project) trials at different hot spot locations and reported a high degree of resistance of the gene pyramided lines indicating broad spectrum resistance conferred by combination of three BB resistance genes. Sundaram et al. (2009) again showed that NILs possessing a combination of $x a 13$ and $X a 21$ in the background of rice variety, Triguna showed high level of resistance to Xoo. Combination of BB resistance genes, xa13 and Xa21 in the background of popular basmati rice variety, Pusa Basmati 1 provided broad-spectrum resistance to BB (Joseph et al., 2004). It can be concluded from the study that 2-gene pyramided lines of popular rice varieties MTU 1010 and JGL 1798 performed better compared to lines possessing single BB resistance gene and can be deployed in the state of Telangana and Andhra Pradesh to combat bacterial blight disease of rice.

\section{ACKNOWLEDGEMENT}

The authors sincerely thank Director, ICAR-Indian Institute of Rice Research (IIRR), Hyderabad and Director of Research, PJTSAU, Hyderabad for the providing facilities.

\section{REFERENCES}

Devadath S (1992). Bacterial Blight of Paddy. In: Singh US, Mukhopadhyay AN, Kumar J and Chaube HS (Eds.), Plant diseases of international importance: Diseases of cereals and pulses, pp: 158-185.

Ellur RK, Khanna A, Yadav A, Pathania S, Rajashekara H, Singh VK, Gopala Krishnan S, Bhowmick PK, Nagarajan M, Vinod KK, Prakash G, Mondal KK, Singh NK, Prabhu KV and Singh AK (2016a). Improvement of Basmati rice varieties for resistance to blast and bacterial blight diseases using marker assisted backcross breeding. Plant Sci. 242: 330341.

Ellur RK, Khanna A, Gopala Krishnan S, Bhowmick PK, Vinod KK, Nagarajan M, Mondal KK, Singh NK, Singh K, Prabhu KV and Singh AK (2016b). Marker-aided Incorporation of Xa38, a Novel Bacterial Blight Resistance Gene, in PB1121 and Comparison of its Resistance Spectrum with xa13+ Xa21. Sci. Rep. 6: 29188.

Gnanamanickam SS (2009). Biological Control of Rice Diseases; Progress in Biological Control, Springer, 108pp.

Hajira Shaik, Yugander A, Balachiranjeevi Ch, Pranathi K, Anila M, Mahadevaswamy M, Kousik MBVN, Dilip Kumar T, Ashok Reddy G, Bhaskar S, Abhilashkumar V, Harika G, Rekha G, Laha GS, Viraktamath BC, Balachandran SM, Neeraja CN, Madhav MS, Mangrauthia SK, Bhadana VP and Sundaram RM (2014). Development of durable bacterial blight resistant lines of samba mahsuri possessing Xa33, Xa21, xa13 \& xa5. Progressive Res. 9: 1224-1227.

Hunjan MS, Singh PP and Lore JS (2014). Virulence frequencies of Xanthomonas oryzae pv. oryzae on different sets of rice differentials under Punjab agro-ecological zones. Indian Phytopath. 67: 20-25.

Hari Y, Srinivasarao K, Viraktamath BC, Hariprasad AS, Laha GS, Ahmed M, Natarajkumar P, Ramesha MS, Neeraja CN, Balachandran SM, Rani NS, Balaji Suresh P, Sujatha K, Pandey M, Ashok Reddy G, Madhav MS and Sundaram RM (2011). Marker-assisted improvement of a stable restorer line KMR-3R and its derived hybrid $\mathrm{KRH} 2$ for bacterial blight resistance and grain quality. Plant Breed. 130: 608-616.

Joseph M, Gopalakrishnan S, Sharma RK, Singh VP, Singh AK, Singh NK and Mohapatra T (2004). Combining bacterial blight resistance and basmati quality characteristics by phenotypic and molecular markerassisted selection in rice. Mol. Breed. 13: 377-387.

Kauffman HE, Reddy APK, Hsieh SPY and Merca SD (1973). An improved technique for evaluating resistance of rice 
varieties to Xanthomonas oryzae. Plant Dis Rep. 57: 537541.

Kim SM, Suh JP, Qin Y, Noh TH, Reinke RF and Jena KK (2015). Identification and fine mapping of a new resistance gene, $X a 40$, conferring resistance to bacterial blight races in rice (Oryza sativa L.). Theor. Appl. Genet. 128: 1933-19943.

Laha GS, Reddy JN, Kumar MN, Rao GJN and Reddy CS (2007). Performance of inbred lines of rice cultivar Swarna with bacterial leaf blight resistance genes. J. Mycol. Plant Pathol. 37: 74-76.

Laha GS, Reddy CS, Krishnaveni D, Sundaram RM, Srinivas Prasad M, Ram T, Muralidharan K and Viraktamath BC (2009). Bacterial Blight of Rice and Its Management. Technical Bulletin No. 41, Directorate of Rice Research (ICAR), Rajendranagar, Hyderabad, India, 37pp.

Laha GS, Sailaja B, Srinivas Prasad M, Ladhalakshmi D, Krishnaveni D, Singh Ram, Prakasam V, Yugander A, Kannan C, Valarmathi P and Ravindra Babu V (2016). Changes in rice disease scenario in India: An analysisfrom Production Oriented Survey. Technical Bulletin No. 91, ICAR-Indian Institute of Rice Research, Rajendranagar, Hyderabad-500 030, Telangana State, India, 95 pp.

Lore JS, Vikal Y, Hunjan MS, Goel RK, Bharaj TS and Raina GL (2011). Genotypic and pathotypic diversity of Xanthomonas oryzae pv. oryzae, the cause of bacterial blight of rice in Punjab state of India. J. Phytopath. 159: 479-487.

Mew TW (1987). Current status and future prospects of research on bacterial blight of rice. Annu. Rev. Phytopathol. 25: 359382.

Mew TW, Vera Cruz CM and Medalla ES (1992). Changes in race frequency of Xanthomonas oryzae pv. oryzae in response to rice cultivars planted in the Philippines. Plant Dis. 76: 1029-1032.

Mishra D, Vishnupriya MR, Anil MG, Kotilingam K, Raj Y and Sonti RV (2013). Pathotype and genetic diversity amongst Indian isolates of Xanthomonas oryzae pv. oryzae. Plos One 8: 1-11.

Mondal KK, Meena BR, Junaid A, Verma G, Mani C, Majumdar D, Khicher M, Kumar S, and Banik S (2014). Pathotyping and genetic screening of type III effectors in Indian strains of Xanthomonas oryzae pv. oryzae causing bacterial leaf blight of rice. Physiol. Mol. Plant Pathol.86: 98-106.

Priyadarisini BV and Gnanaminckam SS (1999). Occurrence of a subpopulation of Xanthomonas oryzae pv. oryzae with virulence to rice CV. IRBB21 (Xa21) in Southern India. Plant Dis. 83: 781.

Ronald PC, Albano B, Tabien R, Abenes L, Wu K, McCouch S and Tanksley S (1992). Genetic and physical analysis of the rice bacterial blight resistance locus, Xa21. Mol. Gen. Genet. 235: 113-120.

Salgotra RK, Gupta BB, Millwood RJ, Balasubramaniam MK and Stewart CN (2012). Introgression of bacterial leaf blight resistance and aroma genes using functional markerassisted selection in rice (Oryza sativa L.). Euphytica 187: 313-323.

Sridhar R (2002). Use of molecular tools for understanding bacterial blight pathogen populations of rice and usefulness of disease resistance genes. Indian Phytopath. 55: 417-429.

Sundaram RM, Vishnupriya MR, Biradar SK, Laha GS, Reddy GA, Rani NS, Sharma NP and Sonti RV (2008). Marker assisted introgression of bacterial blight resistance in Samba Mahsuri, an elite indica rice variety. Euphytica 160: 411-422.

Sundaram RM, Vishnupriya MR, Laha GS, Rani NS, Srinivas Rao P, Balachandran SM, Reddy GA, Sharma NP and Sonti RV (2009). Introduction of bacterial blight resistance into Triguna, a high yielding, mid-early duration rice variety by molecular marker assisted breeding. Biotechnol. J. 4: 400-407.

Sundaram RM, Laha GS, Viraktamath BC, Sujatha K, Natarajkumar P, Hari Y, Srinivasa Rao K, Reddy CS, Balachandran SM, Madhav MS, Hajira SK, Rani NS, Vishnupriya MR and Sonti RV (2011). Marker Assisted Breeding For evelopment of Bacterial Blight Resistant Rice. In: Muralidharan K and Siddiq EA (eds.) Genomics and Crop Improvement: Relevance and Reservations, Institute of Biotechnology, Acharya NG Ranga Agricultural University, Hyderabad. 154-182

Sundaram RM, Madhav MS, Balachandran SM, Neeraja CN, Mangrauthia SK, Padmavathi G, Bhadana VP, Laha GS, Prasad MS, Krishnaveni D, Bentur JS, Padmakumar AP, Katti G, Jhansi Lakshmi V, Shobha Rani N and Viraktamath BC (2014). Marker-assisted selection for Biotic Stress Resistance in Rice. Technical Bulletin No. 79, Directorate of Rice Research, Rajendraganar, Hyderabad, Andhra Pradesh, India, $80 \mathrm{p}$.

Win KM, Korinsaka S, Sirithunya P, Siangliwa JL, Jamboonsri W, Da T, Wadol SP and Toojindaa T (2013). Marker assisted introgression of multiple genes for bacterial blight resistance into aromatic Myanmar rice MK-75. Field Crops Res. 154: 164-171.

Yugander A, Sundaram RM, Ladhalakshmi D, Hajira SK, Madhav MS, Prasad MS, Viraktamath BC and Laha GS (2014). Pathogenic and genetic profile of Xanthomonas oryzae pv. oryzae isolates from Andhra Pradesh. Indian J. Plant Prot. 42: 149-155.

Yugander A, Sundaram RM, Ladhalakshmi D, Hajira SK, Prakasam V, Prasad MS, Madhav MS, Ravindra Babu V and Laha GS (2017). Virulence profiling of Xanthomonas oryzae pv. oryzae isolates, causing bacterial blight of rice in India. Eur. J. Plant Pathol. 149: 171-191.

Zheng K, Huang N, Bennett J and Khush GS (1995). PCRbased marker assisted selection in rice breeding. IRRI Discussion Paper Series No. 12. International Rice Research Institute, Manila, the Philippines. 24pp. 